Katarzyna lłowiecka

\title{
PROCEDURA KONTRAKTOWANIA ŚWIADCZEŃ PRZEZ NARODOWY FUNDUSZ ZDROWIA. PRÓBA ANALIZY SWOT
}

\section{Wprowadzenie}

Celem artykułu jest ocena mocnych i słabych stron procedury zawierania umów przez Narodowy Fundusz Zdrowia ze świadczeniodawcami, a także szans i zagrożeń mających wpływ na przebieg tej procedury. Narzędziem służącym dokonaniu tej oceny będzie analiza SWOT. Analizie poddano następujące obszary, które mają wpływ na kontraktowanie świadczeń: źródła finansowania świadczeń, planowanie zakupu świadczeń, wycena świadczeń oraz przebieg postępowań w sprawie zawarcia umów.

W pierwszej części artykułu przedstawiono sposób zawierania umów przez Narodowy Fundusz Zdrowia (zwany dalej „Funduszem” lub „płatnikiem”), w kolejnych - zidentyfikowane słabe i mocne strony procedury kontraktowania świadczeń, a także szanse i zagrożenia, które mają wpływ na realizację tej procedury.

\section{Przebieg procesu zawierania umów (kontraktowania świadczeń opieki zdrowotnej)}

Kontraktowanie świadczeń zostało uregulowane w Ustawie z dnia 27 sierpnia 2004 r. o świadczeniach opieki zdrowotnej finansowanych ze środków publicznych ${ }^{1}$, zwanej dalej „ustawą o świadczeniach”. Zawarcie umowy pomiędzy płatnikiem i świadczeniodawcą odbywa się w drodze konkursu ofert albo rokowań. Rokowania są uproszczonym trybem, który może być zastosowany tylko w trzech sytuacjach,

1 DzU 2015, poz. 581 z późn. zm. 
określonych w ustawie o świadczeniach ${ }^{2}$. Postępowanie o zawarcie umów jest przeprowadzane przez komisję konkursową, składającą się z minimum 5 pracowników oddziału wojewódzkiego Funduszu³. Postępowanie składa się z części jawnej i niejawnej. W części jawnej komisja w obecności oferentów stwierdza, czy złożone oferty są kompletne, spełniają wymagania określone w przepisach oraz zarządzeniach wydanych przez płatnika. Oferty, które nie zostały odrzucone w części jawnej postępowania, zostają zakwalifikowane do części niejawnej, podczas której komisja porównuje oferty i dokonuje wyboru najkorzystniejszej (lub kilku najkorzystniejszych). Porównanie ofert odbywa się w oparciu o kryteria oceny określone przez ministra zdrowia ${ }^{4}$.

W przypadku kryterium jakości ocenia się przede wszystkim kwalifikacje personelu (np. procentowy udział lekarzy specjalistów w ogólnej liczbie lekarzy), posiadanie aparatury medycznej (np. aparatu ultrasonograficznego w miejscu udzielania świadczeń), posiadanie przez oferenta akredytacji ${ }^{5}$ lub certyfikatu ISO. Od 2007 r. w ramach kryterium jakości zaczęto również oceniać dotychczasową realizację umów zawartych z Funduszem przez świadczeniodawców. Kolejnym kryterium jest ciągłość procesu leczenia. W jego ramach Fundusz ocenia, czy oferent realizuje świadczenia w różnych rodzajach świadczeń, np. czy pacjent po hospitalizacji może otrzymać świadczenia rehabilitacyjne. Od 2014 r. w ramach kryterium ciągłości przyznawane są również dodatkowe punkty świadczeniodawcom, którzy mają już zawartą umowę na dany zakres świadczeń i na określony obszar postępowania. Kolejnym kryterium oceny jest dostępność; w ramach tego kryterium Fundusz ocenia liczbę godzin pracy placówki oraz brak barier architektonicznych dla osób

2 Zgodnie z art. 144 ustawy o świadczeniach rokowania mogą być przeprowadzone, jeśli: 1) uprzednio prowadzone postępowanie $\mathrm{w}$ trybie konkursu ofert zostało unieważnione, a szczegółowe warunki postępowania w sprawie zawarcia umowy są takie same jak w konkursie ofert lub 2) zachodzi pilna potrzeba zawarcia umowy o udzielanie świadczeń opieki zdrowotnej, której wcześniej nie można było przewidzieć, lub 3) jest ograniczona liczba świadczeniodawców, nie większa niż pięciu, mogących udzielać świadczeń opieki zdrowotnej będących przedmiotem postępowania.

3 Sposób ogłaszania postępowania, jego przebieg oraz zadania komisji konkursowej są określone w Rozporządzeniu Ministra Zdrowia z dnia 22 grudnia 2014r. w sprawie sposobu ogłaszania o postępowaniu w sprawie zawarcia umowy o udzielanie świadczeń opieki zdrowotnej, składania ofert, powoływania i odwoływania komisji konkursowej, jej zadań oraz trybu pracy, DzU 2014, poz. 1980.

4 Do sierpnia 2016 r. kryteria oceny ofert były określane przez prezesa Narodowego Funduszu Zdrowia w drodze zarządzeń. Od września $2016 \mathrm{r}$. tę kompetencję przejął minister zdrowia. Obecnie obowiązujące kryteria oceny ofert zostały określone w Rozporządzeniu Ministra Zdrowia z dnia 5 sierpnia 2016r. w sprawie szczegółowych kryteriów oceny ofert w postępowaniu w sprawie zawarcia umów o udzielanie świadczeń opieki zdrowotnej, DzU 2016, poz. 1372.

5 O akredytację mogą wystąpić jedynie świadczeniodawcy udzielający świadczeń w trybie stacjonarnym (szpitale) oraz świadczeniodawcy realizujący świadczenia w rodzaju podstawowa opieka zdrowotna oraz leczenie uzależnień; w przypadku innych świadczeń, np. w rodzaju ambulatoryjna opieka specjalistyczna, minister zdrowia nie wydaje obecnie akredytacji. Dokładne dane dotyczące zakresu akredytacji można znaleźć na stronie internetowej Centrum Monitorowania Jakości w Ochronie Zdrowia, www.cmj.org.pl 
niepełnosprawnych. W kryterium kompleksowości Fundusz promuje tych świadczeniodawców, którzy w ramach jednego zakresu świadczeń (np. w ramach laryngologii) realizują świadczenia w sposób kompleksowy, np. gwarantują dostęp do diagnostyki laboratoryjnej, świadczą usługi zarówno zachowawcze (np. badanie, porada), jak i zabiegowe (np. drobne operacje).

Ostatnim kryterium jest cena świadczenia. Zaproponowana cena jest porównywana $\mathrm{z}$ ceną oczekiwaną przez Fundusz. Cena oczekiwana jest podawana przez Fundusz przed ogłoszeniem postępowania.

Największą wagę w ostatecznej ocenie ma kryterium jakości (30-40\% ogólnej oceny w zależności od zakresu świadczeń), następnie kryterium kompleksowości - odpowiednio 10-15\%, najmniej zaś kryterium dostępności oraz ciągłości - około $5 \%$. Cena wpływa na ostateczną ocenę oferty w około $20 \%$.

Suma punktów uzyskanych w ramach poszczególnych kryteriów wyznacza miejsce oferty w rankingu końcowym. Oferenci, których oferty uzyskały największą liczbę punktów, otrzymują propozycję zawarcia umowy z Funduszem.

Jeśli nie nastąpiło unieważnienie postępowania ${ }^{6}$, komisja ogłasza jego wyniki. Oferentom przysługują środki odwoławcze - protest lub skarga (składane w trakcie postępowania) oraz odwołanie od wyników postępowania. Do czasu jego rozpatrzenia wstrzymuje się zawarcie umowy o udzielanie świadczeń opieki zdrowotnej. Po rozpatrzeniu odwołania dyrektor oddziału wojewódzkiego Funduszu wydaje decyzję administracyjną, uwzględniającą lub oddalającą odwołanie. Od tej decyzji przysługuje wniosek o ponowne rozpatrzenie sprawy, który można złożyć do dyrektora oddziału wojewódzkiego Funduszu. Decyzja wydana na skutek ponownego rozparzenia sprawy podlega natychmiastowemu wykonaniu. Od tej decyzji świadczeniodawcy przysługuje skarga do sądu administracyjnego. W przypadku uwzględnienia odwołania przeprowadza się rokowania ze świadczeniodawcą, którego odwołanie zostało uwzględnione.

6 Zgodnie z art. 150 ustawy o świadczeniach postępowanie konkursowe może zostać unieważnione, jeśli: 1) nie wpłynęła żadna oferta; 2) wpłynęła jedna oferta niepodlegająca odrzuceniu, chyba że z okoliczności wynika, że na ogłoszony ponownie na tych samych warunkach konkurs ofert nie wpłynie więcej ofert; 3) odrzucono wszystkie oferty; 4) kwota najkorzystniejszej oferty przewyższa kwotę, którą Fundusz przeznaczył na finansowanie świadczeń opieki zdrowotnej w danym postępowaniu; 5) nastąpiła istotna zmiana okoliczności powodująca, że prowadzenie postępowania lub zawarcie umowy nie leży w interesie ubezpieczonych, czego nie można było wcześniej przewidzieć. 


\section{Analiza SWOT procesu kontraktowania świadczeń}

Kontraktowanie świadczeń jest jednym z narzędzi regulowania podaży na rynku świadczeń zdrowotnych. Konieczność wprowadzenia regulacji wynika ze specyfiki rynku świadczeń ${ }^{7}$ a w szczególności z występującej tu asymetrii informacji, wysokiej niepewności towarzyszącej zawieranym transakcjom oraz występujących efektów zewnętrznych. Współistnienie tych cech sprawia, że mechanizmy alokacji rynkowej zawodzą, dlatego też państwo tworzy szereg regulacji, które mają na celu wspieranie (lub zastępowanie) mechanizmów rynkowych. Dodatkowo, w przypadku opieki zdrowotnej oczekuje się, że państwo będzie nadzorowało sprawiedliwą jej dystrybucję, tj. zgodną z zasadami sprawiedliwości i zachowania godności jednostki. Z tego względu państwo poprzez regulacje dokonuje korekty alokacji rynkowej w sytuacji, gdy jej wyniki uzna za niesprawiedliwe ${ }^{8}$.

Tworząc system kontraktowania świadczeń, należy wziąć pod uwagę specyfikę zasobów, czyli przede wszystkim:

1) przestrzeń związaną z lokalizacją niemobilnej inwestycji w miejscu najbardziej dogodnym dla stron transakcji z punktu widzenia oszczędności w kosztach magazynowania i transportu - w przypadku rynku zdrowia dotyczy to np. lokalizacji szpitali w dużych ośrodkach miejskich lub w pobliżu węzłów komunikacyjnych; korzystna lokalizacja świadczeniodawcy jest brana pod uwagę przy zawieraniu kontraktów;

2) zasób rzeczowy rozumiany jako wyspecjalizowane maszyny i urządzenia, zaprojektowane w celu realizacji danej transakcji - w opiece zdrowotnej praktycznie cały sprzęt medyczny jest zasobem specyficznym, gdyż nie można go wykorzystać w sposób alternatywny;

3) kapitał ludzki rozumiany jako wiedza, umiejętności i doświadczenie pracowników, które pozwalają im wytwarzać dane dobro efektywniej w porównaniu z innymi osobami nieposiadającymi tych umiejętności i wiedzy - wykształcenie

7 Specyfika rynku świadczeń zdrowotnych została dokładnie opisana w literaturze, np. J.K. Arrow, Uncertainty and the welfare economics of medical care, „The American Economic Review” 1963, Vol. 53, No. 5, s. 941-973; W.C. Hsiao, Abnormal economics in the health sector, „Health Policy” 1995, No. 32, s. 125-139; T. Getzen, Ekonomika zdrowia, tłum. M. Jakubiak, T. Żukowski, Warszawa 2000; S. Morris, N. Devlin, D. Parkin, Ekonomia w ochronie zdrowia, tłum. E. Nojszewska, M. Próchniak, P. Ciżkowicz, Warszawa 2011.

8 Od ekonomii do ekonomii zdrowia. Podręcznik ekonomiki zdrowia, red. S. Golinowska, Wydawnictwo Naukowe PWN, Warszawa 2015, s. 94.

9 O. Williamson, Ekonomiczne instytucje kapitalizmu, Wydawnictwo Naukowe PWN, Warszawa 1998, s. 68 . 
medyczne stanowi zasób specyficzny, koszt alternatywny jego wykorzystania $\mathrm{w}$ innej branży niż medyczna jest bardzo niski;

4) zasoby dedykowane, rozumiane jako inwestycja zrealizowana wyłącznie na zamówienie konkretnego nabywcy - w przypadku rynku zdrowia może to być np. budowa centrum medycznego specjalizującego się w leczeniu chorób rzadkich;

5) znak firmowy zapewniający lojalność klientów dzięki wcześniejszym inwestycjom w jakość produktu, reklamę i promocję - również coraz częściej spotykany na rynku świadczeń zdrowotnych, w szczególności dotyczy świadczeniodawców o wysokiej wiarygodności (skuteczności leczenia) lub konkretnych lekarzy, którzy wypracowali sobie własną „markę”.

Specyfika zasobów powoduje silną współzależność stron oraz wzrost zagrożenia oportunistycznymi zachowaniami kontrahenta. Właściciel specyficznych zasobów może bowiem próbować narzucić wyższą cenę, natomiast odbiorca może dążyć do obniżenia ceny w porównaniu z poziomem uzgodnionym pierwotnie w kontrakcie. W obu wypadkach konieczne jest renegocjowanie warunków umowy, co zwiększa koszty transakcyjne. Receptą na kontraktowanie zasobów specyficznych jest zawieranie kontraktów długoterminowych oraz opracowanie jasnych zasad przed zawarciem kontraktu.

Mając na uwadze zawodność alokacyjną rynku świadczeń, należy bardzo rozważnie modelować proces kontraktowania świadczeń. Poniżej zostanie przeprowadzona analiza SWOT obecnego modelu kontraktowania, uwzględniająca następujące obszary: 1) źródła finansowania świadczeń - analiza tego obszaru jest bardzo istotna, gdyż wysokość środków finansowych, którymi dysponuje Fundusz, determinuje liczbę i rodzaj zakupionych świadczeń;

2) planowanie zakupu świadczeń - jest to proces poprzedzający nabywanie świadczeń; polega na zdiagnozowaniu potrzeb zdrowotnych, określeniu priorytetów oraz właściwym podziale ograniczonych środków finansowych zgodnie z wyznaczonymi priorytetami;

3) wycena świadczeń - ma istotne znaczenie w procesie kontraktowania i wpływa na liczbę i strukturę zakupionych świadczeń;

4) zakup świadczeń - dotyczy ściśle procesu wyboru świadczeniodawców, z którymi zostanie zawarta umowa.

Analiza zostanie przeprowadzona z perspektywy płatnika jako instytucji kontraktującej świadczenia. 
Tabela 1. Analiza SWOT procesu kontraktowania świadczeń

\begin{tabular}{|c|c|c|c|c|}
\hline $\begin{array}{c}\text { Analizowany } \\
\text { obszar }\end{array}$ & Mocne strony & Stabe strony & Szanse & Zagrożenia \\
\hline $\begin{array}{l}\text { Żródła } \\
\text { finansowania } \\
\text { świadczeń }\end{array}$ & $\begin{array}{l}\text { - Przychody Funduszu systematycznie } \\
\text { rosną } \\
\text { - Fundusz samodzielnie zarząadza } \\
\text { środkami finansowymi } \\
\text { - Fundusz decyduje o podziale środków } \\
\text { finansowych na poszczególne rodzaje } \\
\text { i zakresy świadczeń }\end{array}$ & $\begin{array}{l}\text { - Fundusz nie ma wpływu } \\
\text { na wysokość środków } \\
\text { finansowych }\end{array}$ & $\begin{array}{l}\text { - Jasno określone źródła przychodów } \\
\text { i określona wysokość składki } \\
\text { na ubezpieczenie zdrowotne } \\
\text { - Ubezpieczenie zdrowotne jest } \\
\text { obowiązkowe } \\
\text { - Systematyczny wzrost nakładów } \\
\text { na opiekę zdrowotná } \\
\text { - Rozwój ubezpieczeń prywatnych }\end{array}$ & $\begin{array}{l}\text { - Wysokość wpływów ze składki } \\
\text { uzależniona od sytuacji gospodarczej } \\
\text { - Relatywnie niski udział wydatków } \\
\text { na opiekę zdrowotną w PKB } \\
\text { - Niedofinansowanie sektora opieki } \\
\text { zdrowotnej } \\
\text { - Zbyt duże obciążenie gospodarstw } \\
\text { domowych finansowaniem świadczeń } \\
\text { z własnej kieszeni }\end{array}$ \\
\hline $\begin{array}{l}\text { Planowanie } \\
\text { zakupu } \\
\text { świadczeń }\end{array}$ & $\begin{array}{l}\text { - Plany zakupu świadczeń tworzone } \\
\text { w sposób jednolity we wszystkich } \\
\text { OW NFz; zmiana planu wymaga } \\
\text { uzasadnienia } \\
\text { - Fundusz przy tworzeniu planów zakupu } \\
\text { uwzględnia priorytety zdrowotne oraz } \\
\text { mapy potrzeb zdrowotnych } \\
\text { - Fundusz gromadzi wiarygodne } \\
\text { informacje dotyczace podaży oraz } \\
\text { gromadzi i analizuje dane dotyczące } \\
\text { wykonania świadczeń w latach } \\
\text { ubiegłych, co ułatwia oszacowanie } \\
\text { popytu na świadczenia zdrowotne } \\
\text { - Fundusz tworzy plany zabezpieczenia } \\
\text { świadczeń z dokładnością do } \\
\text { obszaru kontraktowania oraz planuje } \\
\text { maksymalną liczbę umów, która } \\
\text { może być zawarta - w ten sposób } \\
\text { zarządza dostępem terytorialnym } \\
\text { i może sterować liczbą zawartych } \\
\text { umów (np. zapobiegać zbytniemu ich } \\
\text { rozdrobnieniu) } \\
\text { - Czéść umów zawartych ze } \\
\text { świadczeniodawcami jest } \\
\text { wieloletnia, co pozytywnie wpływa } \\
\text { na zabezpieczenie świadczeń }\end{array}$ & $\begin{array}{l}\text { - Plan zakupu świadczeń jest } \\
\text { krótkookresowy - dotyczy } \\
\text { roku kalendarzowego } \\
\text { - Fundusz musi limitować } \\
\text { świadczenia i decydować, } \\
\text { które z nich są priorytetowe } \\
\text { - Fundusz musi przewidzieć } \\
\text { rezerwę finansową } \\
\text { na świadczenia wykonane } \\
\text { ponad limity określone } \\
\text { w umowach } \\
\text { - Sprawozdawczość dotycząca } \\
\text { wykonania świadczeń może } \\
\text { być wypaczona metodą } \\
\text { finansowania świadczeń, } \\
\text { z tego względu trudno na jej } \\
\text { podstawie określić popyt } \\
\text { na świadczenia }\end{array}$ & $\begin{array}{l}\text { - Zdefiniowany koszyk świadczeń } \\
\text { gwarantowanych } \\
\text { - Określony ustawowo tryb tworzenia } \\
\text { planu finansowego NFZ } \\
\text { - Od } 2015 \text { r. obowiazzują przepisy } \\
\text { dotyczace obligatoryjnego tworzenia } \\
\text { map potrzeb zdrowotnych oraz } \\
\text { opracowania przez wojewodów } \\
\text { priorytetów zdrowotnych } \\
\text { - Sprawozdawczość dotycząca kolejek } \\
\text { oczekujących jest obowiazzowa } \\
\text { i stanowi źródto informacji o popycie } \\
\text { na świadczenia }\end{array}$ & $\begin{array}{l}\text { - Niedofinansowanie sektora opieki } \\
\text { zdrowotnej } \\
\text { - Brak procedur dotyczących planowania } \\
\text { świadczeń, które gwarantowałyby } \\
\text { kompleksowe planowanie świadczeń, } \\
\text { z wąaczeniem wielu aktorów rynku } \\
\text { świadczeń } \\
\text { - Brak danych kosztowych } \\
\text { - świadczeniodawcy nie mają } \\
\text { obowiazzku ich przekazywania } \\
\text { - Brak rzetelnej sprawozdawczości } \\
\text { dotyczacej kolejek oczekujących } \\
\text { na świadczenia (brakuje jednej bazy } \\
\text { danych zarzaddzanej centralnie) } \\
\text { - Brak narzędzi służacych } \\
\text { kompleksowemu zarządzaniu } \\
\text { zasobami w opiece zdrowotnej (w tym } \\
\text { zasobami kadrowymi, sprzętowymi, } \\
\text { infrastrukturą) } \\
\text { - Brak powiazzania pomiędzy kształceniem } \\
\text { kadry medycznej a potrzebami } \\
\text { zdrowotnymi zglaszanymi przez } \\
\text { pacjentów } \\
\text { - Niedostosowana struktura } \\
\text { świadczeniodawców do potrzeb } \\
\text { zgłaszanych przez pacjentów }\end{array}$ \\
\hline
\end{tabular}




\begin{tabular}{|c|c|c|c|c|}
\hline $\begin{array}{c}\text { Analizowany } \\
\text { obszar }\end{array}$ & Mocne strony & Stabe strony & Szanse & Zagrożenia \\
\hline & $\begin{array}{l}\text { - Przy tworzeniu planu zakupu świadczeń } \\
\text { Fundusz uwzględnia dane GUS oraz } \\
\text { PZH dotyczące epidemiologii i zmian } \\
\text { demograficznych, a także informacje } \\
\text { dotyczące kolejek oczekujących } \\
\text { na świadczenia } \\
\text { - Fundusz może zawierać umowy } \\
\text { wieloletnie (na } 5 \text { lat w przypadku } \\
\text { opieki ambulatoryjnej oraz } \\
\text { na } 10 \text { lat w przypadku leczenia } \\
\text { szpitalnego, a w przypadku } \\
\text { podstawowej opieki zdrowotnej umowy } \\
\text { można zawrzeć bezterminowo) }\end{array}$ & & & $\begin{array}{l}\text { - Brak przepisów ułatwiających } \\
\text { (wymuszających) współpracę pomiędzy } \\
\text { świadczeniodawcami }\end{array}$ \\
\hline $\begin{array}{l}\text { Wycena } \\
\text { świadczeń }\end{array}$ & $\begin{array}{l}\text { - Fundusz wycenia świadczenia } \\
\text { w oparciu o dane z AOTMiT } \\
\text { - Cena świadczeń jest uzgadniana ze } \\
\text { świadczeniodawcą w trybie negocjacji } \\
\text { - Fundusz gromadzi dane dotyczące } \\
\text { finansowania świadczeń, realizacji } \\
\text { umów, nadwykonań i niedowykonań, } \\
\text { które są pomocne w szacowaniu } \\
\text { wartości świadczeń }\end{array}$ & $\begin{array}{l}\text { - Brak danych dotyczących } \\
\text { rzeczywistych kosztów } \\
\text { udzielanych świadczeń } \\
\text { - Ograniczony budżet Funduszu } \\
\text { - Cena świadczeń } \\
\text { jest uzgadniana ze } \\
\text { świadczeniodawcą w trybie } \\
\text { negocjacji, co powoduje duże } \\
\text { napięcia i generuje wysokie } \\
\text { koszty transakcyjne }\end{array}$ & $\begin{array}{l}\text { - Zdefiniowany koszyk świadczeń } \\
\text { gwarantowanych } \\
\text { - Powołanie Agencji Oceny Technologii } \\
\text { Medycznych i Taryfikacji (AOTMiT), } \\
\text { której zadaniem jest m.in. taryfikacja } \\
\text { świadczeń (niezależna od płatnika } \\
\text { taryfikacja świadczeń) } \\
\text { - Ustawowe zobowiązanie podmiotów } \\
\text { finansujących świadczenia } \\
\text { (płatników) do nieodpłatnego } \\
\text { przekazywania danych AOTMiT } \\
\text { dotyczących finansowania } \\
\text { świadczeń } \\
\text { Od 2015r. wprowadzono możliwość } \\
\text { zawierania przez AOTMiT umów } \\
\text { ze świadczeniodawcami w celu } \\
\text { przekazywania danych kosztowych } \\
\text { - warunkiem zawarcia umowy jest } \\
\text { m.in. stosowanie standardowego } \\
\text { rachunku kosztów wg wskazówek } \\
\text { określonych przez ministra zdrowia }\end{array}$ & $\begin{array}{l}\text { - Dane potrzebne do wyceny świadczeń } \\
\text { gromadzi płannik, natomiast wyceny } \\
\text { dokonuje AOTMiT } \\
\text { - Niewystarczająca wspótpraca między } \\
\text { instytucjami odpowiedzialnymi } \\
\text { za gromadzenie i analizę danych } \\
\text { kosztowych } \\
\text { - Trudność w porównaniu i analizie } \\
\text { danych kosztowych ze względu na brak } \\
\text { standardowego rachunku kosztów } \\
\text { - Wycena świadczeń może być wyższa } \\
\text { niż możliwości sfinansowania ich przez } \\
\text { płatnika } \\
\text { - Brak obowiązku udostępniania danych } \\
\text { - kosztowych przez świadczeniodawców } \\
\text { zdrofinansowanie sektora opieki } \\
\text { zdrowotnej }\end{array}$ \\
\hline
\end{tabular}




\begin{tabular}{|c|c|c|c|c|}
\hline $\begin{array}{c}\text { Analizowany } \\
\text { obszar }\end{array}$ & Mocne strony & Stabe strony & Szanse & Zagrożenia \\
\hline $\begin{array}{l}\text { Zakup } \\
\text { świadczeń }\end{array}$ & $\begin{array}{l}\text { - Fundusz ustala warunki zawierania } \\
\text { umów w trybie konsultacji ze } \\
\text { środowiskiem medycznym, co może } \\
\text { zmniejszać koszty transakcyjne } \\
\text { - Fundusz decyduje o okresie, na jaki } \\
\text { zawierane są umowy } \\
\text { - Funduszz zwiększa wymagania } \\
\text { jakościowe } \\
\text { - Fundusz wybiera świadczeniodawców, } \\
\text { z którymi zawiera umowe } \\
\text { - Fundusz decyduje o rozmieszczeniu } \\
\text { świadczeniodawców (alokacji } \\
\text { terytorialnej) poprzez określenie } \\
\text { obszarów kontraktowania } \\
\text { - Fundusz zawiera długoletnie kontrakty } \\
\text { (wspótpraca jest wieloletnia) } \\
\text { - Płatnik definiuje jednolite zasady } \\
\text { kontraktowania, obowiązujące w całym } \\
\text { kraju } \\
\text { - Kontraktowanie świadczeń pozwala } \\
\text { na ograniczenie kosztów oraz } \\
\text { na określenie limitów świadczeń } \\
\text { (ograniczenia popytu) } \\
\text { - Płatnik stosuje zróżnicowane modele } \\
\text { finansowania świadczeń } \\
\text { Cześć świadczé́ nielimitowana } \\
\text { (np. porody, świadczenia udzielane } \\
\text { w ramach tzw. szybkiej ścieżki } \\
\text { onkologicznej) } \\
\text { - Fundusz może określić maksymalną } \\
\text { liczbe zawieranych umów - jest } \\
\text { to jedyne narzędzie, poza określeniem } \\
\text { obszarów kontraktowania, } \\
\text { zapobiegające nadmiernemu } \\
\text { rozdrobnieniu liczby kontraktów }\end{array}$ & $\begin{array}{l}\text { - Struktura zasobów } \\
\text { (kadrowych, lokalowych) } \\
\text { świadczeniodawców } \\
\text { nieadekwatna do zglaszanego } \\
\text { popytu } \\
\text { - Liczba i cena świadczeń } \\
\text { określona w drodze negocjacji, } \\
\text { w trakcie których strony } \\
\text { wywierają naciski zagrażające } \\
\text { stabilizacji systemu opieki } \\
\text { zdrowotnej } \\
\text { - Fundusz jest zobowiązany do } \\
\text { weryfikacji każdej złożonej } \\
\text { oferty pod kątem spełnienia } \\
\text { wymagań formalnych, co } \\
\text { prowadzi do wzrostu kosztów } \\
\text { transakcyjnych } \\
\text { Ograniczone zaufanie } \\
\text { stron zawieranych umów } \\
\text { prowadzi do wzrostu kosztów } \\
\text { transakcyjnych i napięć } \\
\text { w trakcie kontraktowania } \\
\text { świadczeń } \\
\text { - Konkursy często odbywają } \\
\text { się tuż przed wygaśnięciem } \\
\text { poprzednich umów, } \\
\text { co może prowadzić do } \\
\text { niezabezpieczenia świadczeń } \\
\text { - Świadczenia są limitowane, } \\
\text { co rodzi wiele napię́c podczas } \\
\text { negocjacji } \\
\text { - Zagrożenie ciągłości } \\
\text { opieki w przypadku, gdy } \\
\text { w postępowaniu na kolejny } \\
\text { rok świadczeniodawca traci } \\
\text { kontrakt } \\
\text { Brak narzędzi do rzetelnej } \\
\text { wyceny świadczeń przez } \\
\text { Fundusz }\end{array}$ & $\begin{array}{l}\text { - Zdefiniowany koszyk świadczeń } \\
\text { gwarantowanych } \\
\text { - Opublikowane przez ministra } \\
\text { zdrowia mapy potrzeb zdrowotnych } \\
\text { stanowią podstawe, do tworzenia } \\
\text { planów zakupu świadczeń, zawierają } \\
\text { informację o potencjale wytwórczym } \\
\text { świadczeniodawców } \\
\text { - Zdefiniowane przez wojewodów } \\
\text { priorytety zdrowotne } \\
\text { - MZ określa minimalne warunki } \\
\text { wymagane od świadczeniodawców } \\
\text { oraz (od września } 2016 \text { r.) kryteria } \\
\text { wyboru ofert } \\
\text { - Ustawowy obowiązek } \\
\text { rejestrowania niektórych chorób, } \\
\text { np. nowotworowych lub zabiegów, } \\
\text { np. wszczepienia endoprotez } \\
\text { (obowiązkowe zgłaszanie do } \\
\text { rejestru) } \\
\text { - Wprowadzona od } 2015 \text { r. } \\
\text { możliwość zawierania umów } \\
\text { na } 5 \text { lat w ambulatoryjnej opiece } \\
\text { zdrowotnej, na } 10 \text { lat w leczeniu } \\
\text { szpitalnym oraz bezterminowo } \\
\text { w przypadku podstawowej opieki } \\
\text { zdrowotnej } \\
\text { - Od 2015r. wycena świadczeń } \\
\text { poza NFz } \\
\text { - Przedmiotem kontraktowania } \\
\text { są zasoby specyficzne } \\
\text { - Poprawiająca się efektywność } \\
\text { kosztowa i zarzaddcza } \\
\text { świadczeniodawców, co przekłada } \\
\text { się na jakość świadczeń } \\
\text { - Warunki zawierania umów są znane } \\
\text { wczésiej i nie mogą być zmieniane } \\
\text { w trakcie postępowań }\end{array}$ & $\begin{array}{l}\text { - Niskie finansowanie opieki zdrowotnej } \\
\text { - Przedmiotem kontraktowania są zasoby } \\
\text { specyficzne } \\
\text { - Niedostosowana struktura podaży do } \\
\text { popytu w przypadku np. leczniztwa } \\
\text { szpitalnego oraz opieki długoterminowej } \\
\text { - Czeste zmiany otoczenia prawnego } \\
\text { (ustaw, rozporządzeń, zarządzeń } \\
\text { Funduszu) } \\
\text { - Warunki zawierania umów zmieniają } \\
\text { się zbyt często, w wyniku czego } \\
\text { świadczeniodawcom oraz Funduszowi } \\
\text { brakuje czasu na dostosowanie się do } \\
\text { nich } \\
\text { - Umowy zawierane na rok lub } \\
\text { krótsze ze względu na brak zgody } \\
\text { świadczeniodawców na zawieranie } \\
\text { umów wieloletnich } \\
\text { Brak zróżnicowania modeli } \\
\text { kontraktowania świadczeń w zależności } \\
\text { od przedmiotu zakupu oraz w zależności } \\
\text { od poziomu konkurencyjności } \\
\text { (np. dla konkurencyjnego } \\
\text { rynku w ambulatoryjnej opiece } \\
\text { specjalistycznej i niekonkurencyjnego } \\
\text { w lecznictwie zamkniętym) } \\
\text { - Kontraktowanie wąskich zakresów } \\
\text { udzielanych świadczeń, co } \\
\text { utrudnia stworzenie biznesplanu } \\
\text { świadczeniodawcom (np. kontrakt tylko } \\
\text { na jeden oddziat/jedną poradnię) } \\
\text { - Brak wiarygodnych rejestrów } \\
\text { dotyczacych np. powikłań, które } \\
\text { umożiliwiłyby róñicowanie } \\
\text { finansowania świadczeń w zależności } \\
\text { od efektów leczenia } \\
\text { Srodki odwoławcze od wyniku } \\
\text { postępowania są nieefektywne }\end{array}$ \\
\hline
\end{tabular}




\begin{tabular}{|c|c|c|c|c|}
\hline $\begin{array}{c}\text { Analizowany } \\
\text { obszar }\end{array}$ & Mocne strony & Stabe strony & Szanse & Zagrożenia \\
\hline & & $\begin{array}{l}\text { - Rozproszona informacja } \\
\text { dotycząca popytu i podaży } \\
\text { - Fundusz musi finansować } \\
\text { zbyt szeroki koszyk świadczeń } \\
\text { gwarantowanych w stosunku } \\
\text { do wysokości nakładów } \\
\text { finansowych } \\
\text { - Fundusz nie ma narzędzi do } \\
\text { skoordynowania leczenia } \\
\text { pomiędzy podmiotami } \\
\text { udzielającymi świadczeń } \\
\text { - Kontraktowanie wąskich } \\
\text { zakresów udzielanych } \\
\text { świadczeń, co utrudnia } \\
\text { Funduszowi analize } \\
\text { wskaźników jakościowych } \\
\text { oraz zaburza ciągłość leczenia } \\
\text { pacjentów }\end{array}$ & $\begin{array}{l}\text { - Płatnik jest ustawowo zobowiązany } \\
\text { do stosowania zasad uczciwej } \\
\text { konkurencji } \\
\text { - Konkurencja między } \\
\text { świadczeniodawcami wymusza } \\
\text { obniżenie kosztów i wzrost jakości } \\
\text { udzielanych świadczeń } \\
\text { - Wzrastająca umiejętność } \\
\text { dostosowania się } \\
\text { świadczeniodawców do } \\
\text { - zmieniającego się otoczenia } \\
\text { - Wprowadzone ustawowo kryterium } \\
\text { ciągłości udzielania świadczeń jako } \\
\text { kryterium dodatkowo oceniane } \\
\text { - Doprecyzowanie w ustawie } \\
\text { o świadczeniach kryteriów oceny } \\
\text { ofert } \\
\text { - System akredytacji } \\
\text { świadczeniodawców (ograniczony } \\
\text { do wybranych podmiotów) } \\
\text { - Ustawowe wprowadzenie } \\
\text { narzędzi umożliwiających wycenę } \\
\text { świadczeń zdrowotnych opartą } \\
\text { na rzeczywistych i uzasadnionych } \\
\text { kosztach świadczen } \\
\text { - Proces przeprowadzania konkursu } \\
\text { jest uregulowany w ustawie } \\
\text { i rozporządzeniach } \\
\text { - Świadczeniodawcy dysponują } \\
\text { wykwalifikowaną kadrą medyczną } \\
\text { i specjalistycznym sprzętem }\end{array}$ & $\begin{array}{l}\text { - Brak programów koordynujących, } \\
\text { zarządzających leczeniem pacjenta } \\
\text { - r ramach różnych rodzajów świadczeń } \\
\text { - Brak wymiany informacji pomiędzy } \\
\text { świadczeniodawcami } \\
\text { - Niepewność co do zatrudnienia, } \\
\text { kłopoty ze zwrotem kosztów inwestycji } \\
\text { w przypadku utraty kontraktu przez } \\
\text { świadczeniodawców } \\
\text { - Do } 2015 \text { r. wycena świadczeń i podział } \\
\text { środków finansowych należały do } \\
\text { kompetencji jednej instytucji - płatnika } \\
\text { (w } 2015 \text { r. zmiana - wycena świadczeń } \\
\text { należy do kompetencji A0TMiT) } \\
\text { - Niedobór specjalistów w niektórych } \\
\text { dziedzinach medycznych } \\
\text { - Migracja kadry medycznej za granice } \\
\text { - Małe zainteresowanie ubezpieczeniem } \\
\text { - komercyjnym } \\
\text { W przypadku niektórych usług } \\
\text { konieczność przyznania kontraktów } \\
\text { świadczeniodawcom, np. szpitalom } \\
\text { publicznym bez względu na potrzeby } \\
\text { - naciski polityczne } \\
\text { - Brak poziomów referencyjnych szpitali } \\
\text { - Rozproszona informacja nt. } \\
\text { leczenia pacjentów u różnych } \\
\text { świadczeniodawców } \\
\text { - Brak uregulowań prawnych } \\
\text { umożliwiających elektroniczną wymianę } \\
\text { danych } \\
\text { - Nierównomierne rozmieszczenie } \\
\text { kadry medycznej oraz infrastruktury } \\
\text { medycznej } \\
\text { - Niskie znaczenie akredytacji w ochronie } \\
\text { zdrowia - nie jest obligatoryjna }\end{array}$ \\
\hline
\end{tabular}




\begin{tabular}{|c|c|c|c|c|}
\hline $\begin{array}{c}\text { Analizowany } \\
\text { obszar }\end{array}$ & Mocne strony & Stabe strony & Szanse & Zagrożenia \\
\hline $\begin{array}{l}\text { Zakup } \\
\text { świadczeń }\end{array}$ & & & & $\begin{array}{l}\text { - Trudności w dostępie do informacji } \\
\text { kosztowej, informacja niespójna, } \\
\text { brak standardów gromadzenia } \\
\text { i przekazywania danych } \\
\text { - Niewystarczające standardy jakościowe } \\
\text { - Zmniejszanie się zasobów finansowych } \\
\text { Funduszu w związku z sytuacją } \\
\text { gospodarczą (niskie wpływy ze } \\
\text { składek) przy wzrastającym popycie } \\
\text { na świadczenia zdrowotne } \\
\text { - Szkolnictwo medyczne niedostosowane } \\
\text { do zapotrzebowania na rynku } \\
\text { - Niekorzystne zmiany demograficzne } \\
\text { (starzejące się społeczeństwo) oraz } \\
\text { epidemiologiczne (wzrost zachorowań } \\
\text { na choroby przewlekłe) } \\
\text { - Zasoby specyficzne } \\
\text { - Mała elastyczność podaży } \\
\text { - Zjawiska zaburzające alokację } \\
\text { rynkową (popyt indukowany przez } \\
\text { podaż, moralny hazard pacjentów, } \\
\text { działanie prawa Harta - większa podaż } \\
\text { lekarzy nie wpływa na obniżenie ceny } \\
\text { świadczeń) } \\
\text { - Brak dobrego systemu przepływu } \\
\text { informacji oraz brak współpracy } \\
\text { pomiędzy aktorami na rynku świadczeń } \\
\text { opieki zdrowotnej } \\
\text { - Ograniczona konkurencja }\end{array}$ \\
\hline
\end{tabular}

Źródło: Opracowanie własne. 


\section{Ocena wyników analizy SWOT}

\section{1. Źródła finansowania świadczeń opieki zdrowotnej}

Podstawowym źródłem finansowania świadczeń są składki opłacane w ramach obowiązkowego, powszechnego ubezpieczenia zdrowotnego. Część świadczeń, głównie wysokospecjalistycznych lub realizowanych w ramach programów zdrowotnych, jest finansowana $\mathrm{z}$ budżetu państwa. Niektóre świadczenia są współfinansowane przez pacjentów (np. dopłata do leków, częściowa odpłatność za pobyt w sanatorium). Składka na ubezpieczenie zdrowotne wynosi $9 \%$ podstawy wymiaru składki ${ }^{10}$ i jest opłacana przez osobę ubezpieczoną, a odprowadzana przez płatnika składek (przeważnie przez pracodawcę). Składki na ubezpieczenie zdrowotne systematycznie rosną (dokładne dane zawiera tab. 2). Rosną również wydatki na zakup świadczeń finansowanych $\mathrm{z}$ budżetu państwa oraz budżetów jednostek samorządu terytorialnego - w 2012 r. wynosiły one łącznie $6481 \mathrm{mln}$ zł, a w 2013 r. $10178 \mathrm{mln} \mathrm{z}^{11}$.

Tabela 2. Przychody NFZ z tytułu składki na ubezpieczenie zdrowotne oraz wydatki NFZ na zakup świadczeń zdrowotnych ( $\mathrm{w} \mathrm{mln}$ zł)

\begin{tabular}{|l|c|c|c|c|c|}
\hline \multicolumn{1}{|c|}{ Wyszczególnienie } & 2008 & 2010 & 2012 & 2014 & $\begin{array}{c}\text { Dynamika zmian } \\
(2008=100 \%)\end{array}$ \\
\hline $\begin{array}{l}\text { Przychody ze składek na powszechne } \\
\text { ubezpieczenie zdrowotne }\end{array}$ & 50459,59 & 55153,15 & 60312,31 & 64388,83 & 28 \\
\hline $\begin{array}{l}\text { Koszty świadczeń opieki zdrowotnej } \\
\text { poniesione przez NFZ }\end{array}$ & 49322,06 & 56380,31 & 59458,03 & 63198,61 & 28 \\
\hline
\end{tabular}

Źródło: Opracowanie własne na podstawie sprawozdań finansowych NFZ za lata 2008-2014.

Jasno określone źródła przychodów i wysokość składki na ubezpieczenie zdrowotne znacznie ułatwiają proces kontraktowania świadczeń. Jednak, mimo że ubezpieczenie zdrowotne jest obligatoryjne i od momentu jego wprowadzenia wartość środków finansowych na zakup świadczeń systematycznie rośnie, to udział wydatków na zdrowie w PKB wciąż jest niski w porównaniu z krajami UE i wynosi 6,8\%, podczas

10 Wysokość składki była systematycznie zwiększana - zgodnie z art. 242 ustawy o świadczeniach wynosiła odpowiednio: od dnia wejścia w życie ustawy do 31.12.2004 r. - 8,25\% podstawy wymiaru; od 1.01.2005 r. do 31.12 .2005 r. $-8,5 \%$ podstawy wymiaru; od 1.01.2006r. do 31.12.2006r. - 8,75\% podstawy wymiaru; obecnie wynosi $9 \%$.

11 Zdrowie i ochrona zdrowia w 2014 r., Główny Urząd Statystyczny, Warszawa 2015, s. 143. 
gdy średnia dla krajów UE $-8,7 \%{ }^{12}$. Niskie nakłady na opiekę zdrowotną wymuszają na Funduszu limitowanie świadczeń, pomimo to część świadczeniodawców wykonuje świadczenia ponad limit określony w umowie. Ze sprawozdań finansowych NFZ za lata 2013-2014 wynika, że świadczenia ponadlimitowe (tj. niezakontraktowane, ale udzielone w ramach powszechnego ubezpieczenia zdrowotnego) w $2013 \mathrm{r}$. wynosiły 953623 tys. zł, a w 2014 r. - 842653 tys. zł. Świadczeniodawcy podejmują mediacje z Funduszem. W ich wyniku część z tych świadczeń jest sfinansowana przez NFZ. Świadczeniodawcy występują również do sądu i próbują uzyskać zwrot poniesionych kosztów. Z informacji zamieszczonej w sprawozdaniu z działalności NFZ wynika, że w 2014 r. zakończono 282 sprawy przeciwko NFZ z tytułu nadwykonań na kwotę 213230 tys. zł. Spory dotyczące sfinansowania nadwykonań zwiększają koszty transakcyjne, które są ponoszone przez świadczeniodawców oraz podatników.

\subsection{Planowanie zakupu świadczeń}

Atutem planowania zakupu świadczeń jest fakt, że odbywa się ono w oparciu o zdefiniowany koszyk świadczeń gwarantowanych ${ }^{13}$ oraz plan finansowy Funduszu, zatwierdzony przez ministra zdrowia i ministra finansów. Ponadto Fundusz korzysta z danych Głównego Urzędu Statystycznego oraz danych epidemiologicznych gromadzonych przez Państwowy Zakład Higieny. Dodatkowo od 2015 r. ${ }^{14}$ Fundusz dysponuje danymi zawartymi w opublikowanych przez Ministerstwo Zdrowia mapach potrzeb zdrowotnych. Stanowią one narzędzie planistyczne, służące do oceny potrzeb zdrowotnych w województwie. Są tworzone w oparciu o dane epidemiologiczne gromadzone przez Państwowy Zakład Higieny. Na ich podstawie wojewodowie określają priorytety zdrowotne. Mapy zawierają również szczegółowe dane dotyczące infrastruktury i rozmieszczenia świadczeniodawców - te informacje stanowią podstawę do wydania przez wojewodę pozytywnej lub negatywnej opinii o potrzebie powstania nowego świadczeniodawcy w województwie. Fundusz korzysta również z własnych danych, w szczególności dotyczących wykonania umów w latach poprzednich oraz analizy rozmieszczenia bazy lecznictwa i dostępności lekarzy poszczególnych specjalności.

12 W Unii Europejskiej największy udział wydatków na zdrowie w PKB jest w Holandii (11,8\%), najmniejszy zaś na Litwie (6,7\%), Łotwie (5,7\%), Estonii (5,9\%) i Rumunii (5,6\%). Dane dotyczą 2012 r.; podaję za raportem Health at a Glance: Europe 2014, OECD Publishing, www.oecd.org

13 Koszyk świadczeń gwarantowanych został wprowadzony w 2009r. Definiuje go minister zdrowia, wskazując w rozporządzeniach wydanych na podstawie art. 31d ustawy o świadczeniach zakres świadczeń przysługujących w ramach obowiązkowego ubezpieczenia zdrowotnego.

14 W Ustawie z dnia 22 lipca $2014 \mathrm{r}$. o zmianie ustawy o świadczeniach opieki zdrowotnej finansowanych ze środków publicznych oraz niektórych innych ustaw (DzU 2014, poz. 1138) wprowadzono rozdz. IVa „Ocena potrzeb zdrowotnych”, w którym m.in. określono, jakie instytucje są odpowiedzialne za tworzenie map potrzeb zdrowotnych. 
Zagrożeniem procesu planowania jest niedofinansowanie sektora opieki zdrowotnej, co skutkuje koniecznością limitowania świadczeń i określania świadczeń priorytetowych (np. onkologicznych, czego wyrazem jest opracowanie tzw. pakietu onkologicznego). Ponadto brakuje narzędzi pozwalających na kompleksowe zarządzanie zasobami opieki zdrowotnej. W szczególności brakuje korelacji pomiędzy kształceniem kadr medycznych a popytem na usługi lekarzy poszczególnych specjalności zgłaszanym na rynku świadczeń. Brakuje również danych dotyczących rzeczywistych kosztów udzielania świadczeń, gdyż świadczeniodawcy nie mają obowiązku ich sprawozdawania.

Mocną stroną planowania zakupu świadczeń jest fakt, że plany zakupu są tworzone w sposób jednolity we wszystkich oddziałach wojewódzkich Funduszu. Fundusz ma narzędzia do planowania zakupu świadczeń w podziale na poszczególne zakresy świadczeń ${ }^{15}$ oraz obszary kontraktowania ${ }^{16}$, a także może ustalić maksymalną liczbę umów, która zostanie zawarta w ramach obszaru kontraktowania. Fundusz posiada również wiarygodne dane dotyczące potencjału wytwórczego świadczeniodawców oraz ich rozmieszczenia terytorialnego.

Słabą stroną planowania zakupu jest jego krótkookresowy charakter (plany zakupu są tworzone na okres roku). Dodatkowo wiarygodność danych dotyczących popytu na świadczenia (analizowanego na podstawie realizacji umów ze świadczeniodawcami) jest ograniczona ze względu na wpływ sposobu finansowania świadczeń na ich wykonanie ${ }^{17}$.

\subsection{Wycena świadczeń}

Do roku 2014 wyceną świadczeń zajmował się NFZ, obecnie to zadanie zostało powierzone Agencji Oceny Technologii Medycznych i Taryfikacji (AOTMiT). Niezależna od płatnika taryfikacja świadczeń jest atutem procesu wyceny świadczeń, gdyż

15 Zakres świadczeń to świadczenia lub grupa świadczeń, dla których w umowie określono kwotę finansowania, np. alergologia, kardiologia.

16 Obszar kontraktowania - obszar zgodny z podziałem terytorialnym (np. gmina, powiat, województwo), na który dyrektor OW NFZ ogłasza postępowanie; świadczeniodawcy biorący udział w postępowaniu muszą udzielać świadczeń w ramach obszaru kontraktowania.

17 Więcej informacji na temat sposobu finansowania świadczeń oraz jego wpływu na realizację świadczeń (np. zjawisko indukowania popytu przez lekarzy) można znaleźć w: Ch. Phelps, Health Economics, Addison-Wesley 1997; J. Indulski, M. Matulewicz, M. Bryła, Ekonomika zdrowia a problem efektywności ochrony zdrowia, Instytut Medycyny Pracy, Łódź 1994; J. Richardson., S. Peacock, Reconsidering theories of supplier induced demand, Centre for Health Economics, Monash University, Australia, July 2006; L.F. Rossiter, G.R. Wilensky, Identification of Physician - Induced Demand, „The Journal of Human Resources” Spring 1984, Vol. 19, No. 2; M.V. Pauly, The Economics of Moral Hazard: Comment, „The American Economic Review" June 1998, Vol. 58, No. 3. 
AOTMiT ma możliwość zbierania danych kosztowych (Fundusz nie miał takiego narzędzia). Takie rozwiązanie (wycena świadczeń przez instytucję inną niż płatnik) jest stosowane również w innych krajach, np. w Niemczech czy Wielkiej Brytanii. Fundusz oraz inne podmioty finansujące świadczenia są zobowiązane do nieodpłatnego przekazywania wszelkich danych AOTMiT dotyczących finansowania świadczeń. AOTMiT może zawierać umowy ze świadczeniodawcami dotyczące przekazywania danych kosztowych. Dodatkowym, oprócz finansowego, bodźcem dla świadczeniodawców do zawierania takich umów jest przyznanie im punktów podczas postępowań w sprawie zawierania umów z Funduszem - świadczeniodawcy, którzy przekazują dane kosztowe, mają więc większe szanse na zawarcie umów z Funduszem.

Zagrożenia w tym obszarze wiążą się głównie $\mathrm{z}$ faktem, że przy obecnym podziale kompetencji pomiędzy poszczególne instytucje konieczna jest ścisła współpraca między płatnikiem i AOTMiT. Z pewnością AOTMiT spotka się z trudnością w porównaniu i analizie danych kosztowych uzyskanych od świadczeniodawców ze względu na brak standardowego rachunku kosztów. Standardowy rachunek kosztów ma zostać opracowany i wdrożony dopiero w roku 2020. Największym jednak zagrożeniem jest według mnie sytuacja, w której wycena świadczeń przewyższy możliwości finansowe płatnika.

\subsection{Zakup świadczeń}

Płatnik może rozpocząć proces zakupu (kontraktowania) świadczeń dopiero po zatwierdzeniu planu finansowego Funduszu ${ }^{18}$. Warunki wymagane do realizacji świadczeń są określone w rozporządzeniach ministra zdrowia. Dodatkowo Fundusz opracowuje szczegółowe warunki zawierania umów ze świadczeniodawcami.

Atutem zakupu świadczeń są ustalone reguły kontraktowania, z których większość ma rangę ustawową. Dzięki nim proces kontraktowania jest transparentny. Obowiązujące zasady kontraktowania są następujące ${ }^{19}$ :

1) Zasada równego traktowania wszystkich świadczeniodawców - polega na prowadzeniu postępowań w sposób gwarantujący zachowanie uczciwej konkurencji. Wszelkie wymagania, wyjaśnienia i informacje, a także dokumenty związane z postępowaniem udostępniane są świadczeniodawcom na takich samych zasadach. Warunki zawierania umów są publikowane w formie zarządzeń prezesa

18 Plan finansowy Funduszu jest zatwierdzany przez ministra zdrowia i ministra finansów. Od 2015 r. na skutek wejścia w życie ustawy z dnia 22 lipca 2014 r. proces zakupu świadczeń może się rozpocząć nawet przy braku zatwierdzonego planu finansowego - w takiej sytuacji podstawą do opracowania planu zakupu jest plan finansowy, obowiązujący w roku bieżącym.

19 Zasady opracowano na podstawie ustawy o świadczeniach. 
NFZ i zamieszczane na stronie internetowej Funduszu. Warunków tych nie można zmieniać $\mathrm{w}$ trakcie postępowania.

2) Zasada jawności ofert oraz umów zawartych w wyniku postępowania - jest realizowana poprzez zamieszczenie na stronie internetowej Funduszu informacji o każdej zawartej umowie, z uwzględnieniem rodzaju, liczby i ceny zakupionych świadczeń. Zasada jawności ofert jest realizowana poprzez udostępnienie wglądu do nich, o ile informacje w niej zawarte nie zostały zastrzeżone przez świadczeniodawcę jako tajemnica przedsiębiorcy. Oferty są jawne po zakończeniu postępowania.

3) Zasada ograniczonego zaufania do nowych kontrahentów - polega na obligatoryjnej kontroli świadczeniodawców, którzy złożyli ofertę po raz pierwszy w danym zakresie świadczeń. W takim przypadku komisja konkursowa ma obowiązek przeprowadzenia weryfikacji danych zawartych w ofercie ze stanem faktycznym.

4) Zasada planowania rozmieszczenia terytorialnego świadczeniodawców - jest realizowana poprzez przeprowadzanie postępowań ze wskazaniem obszaru, którego dotyczy. Oznacza to, że w postępowaniu mogą wziąć udział świadczeniodawcy udzielający świadczeń w ramach wskazanego obszaru (np. gminy, powiatu, województwa). Celem takiego działania jest zapewnienie odpowiedniej dostępności terytorialnej do świadczeń.

5) Zasada obiektywizmu - polega na konieczności określenia przez Fundusz takich warunków zawierania umów, które nie wykluczają lub nie preferują żadnego ze świadczeniodawców. Przedmiot postępowania musi zostać opisany w sposób jednoznaczny i wyczerpujący. Nie można opisywać przedmiotu zamówienia poprzez wskazanie znaków towarowych lub patentów, chyba że jest to uzasadnione specyfiką przedmiotu zamówienia. Ponadto komisja konkursowa przeprowadzająca postępowanie musi spełniać kryteria określone w ustawie o świadczeniach, przede wszystkim musi być obiektywna i niezwiązana ze świadczeniodawcami biorącymi udział w konkursie.

6) Zasada konsultowania warunków zawierania umów ze środowiskiem medycznym - jest realizowana poprzez ustawowy obowiązek zasięgania opinii izb zrzeszających lekarzy i pielęgniarki, jak również konsultantów wojewódzkich na temat warunków realizacji umów określanych przez prezesa Funduszu. Opinia środowisk medycznych nie jest wiążąca dla prezesa Funduszu.

Wymienione zasady porządkują proces zawierania umów. Ich stosowanie obniża koszty transakcyjne procesu kontraktowania świadczeń. Wadą jest jednak brak zróżnicowania zasad kontraktowania świadczeń w ambulatoryjnej i szpitalnej opiece zdrowotnej. W przypadku opieki ambulatoryjnej konkurs ofert wzmacnia konkurencję między świadczeniodawcami i przyczynia się do podniesienia jakości udzielanych 
świadczeń. Dzieje się tak dlatego, że finansowe bariery wejścia na rynek świadczeń ambulatoryjnych są o wiele niższe aniżeli w przypadku lecznictwa szpitalnego. Budowa szpitala wiąże się z dużymi nakładami finansowymi i z reguły ma znaczenie strategiczne. Szpitale pełnią bardzo ważną funkcję w sferze publicznej i w większości są instytucjami nienastawionymi na zysk. $Z$ tego powodu nie można stosować reguł rynkowych na tak szeroką skalę jak w przypadku leczenia ambulatoryjnego. Moim zdaniem, w przypadku szpitali nie sprawdza się idea wzajemnego porównywania w celu wybrania najlepszej oferty, gdyż takie podejście nie uwzględnia różnorodności szpitali (różnych profili szpitali oraz różnych poziomów referencyjnych ${ }^{20}$ ). Z tego względu uważam, że umowy ze szpitalami nie powinny być zawierane w trybie konkursu ofert, w rzeczywistości bowiem konkurencja między szpitalami jest mocno ograniczona ${ }^{21}$. W praktyce wszystkie szpitale publiczne przystępujące do konkursu otrzymują kontrakt. W przypadku świadczeń wysokospecjalistycznych, np. przeszczepiania organów, trudno znaleźć kryteria różnicujące czy wyróżniające ofertę, gdyż jest niewielu świadczeniodawców, którzy spełniają warunki wymagane do realizacji tych świadczeń. Są to tak specyficzne świadczenia, że podpisywanie umów na ich realizację w trybie konkursu ofert wydaje się bezzasadne i bezcelowe. Moim zdaniem, bardziej efektywnym modelem jest stworzenie sieci szpitali, w której skład wchodziłyby szpitale spełniające określone kryteria jakościowe, odpowiednie do swojego profilu. Ważne byłoby również opracowanie poziomów referencyjnych szpitali. Warto dodać, że tworzenie sieci szpitali nie jest nowym pomysłem i sprawdza się w innych krajach, np. w Niemczech, gdzie włączenie szpitala do sieci szpitali udzielających świadczeń finansowanych ze środków publicznych wiąże się z uzyskaniem pozytywnej opinii ministra zdrowia.

Kolejną wadą obecnego modelu kontraktowania świadczeń jest fragmentacja opieki zdrowotnej. Umowy podpisywane są na wąskie zakresy świadczeń (np. alergologię, kardiologię), natomiast brakuje programów koordynujących całościową opiekę nad pacjentem. Taki sposób kontraktowania znacznie utrudnia postawienie prawidłowej diagnozy oraz wdrożenie właściwego leczenia. Z punktu widzenia świadczeniodawcy taki sposób kontraktowania wymusza składanie przez niego wielu ofert (na realizację każdego zakresu oddzielnie) i utrudnia całościowe zarządzanie

20 Pisząc o poziomie referencyjnym szpitali, mam na myśli zróżnicowanie szpitali pod względem skomplikowania leczonych przypadków. Zazwyczaj do szpitali klinicznych, ze względu na specjalistyczny sprzęt i kwalifikacje kadry medycznej, powinny trafiać bardziej złożone przypadki medyczne, a więc również droższe. Podobnie szpitale profilowane, nastawione na leczenie konkretnych chorób lub konkretnej grupy pacjentów (np. onkologiczne lub pediatryczne) uzyskują lepsze efekty leczenia ze względu na doświadczenie kadry w leczeniu konkretnych chorób. Obecnie jednak przepisy nie definiują poziomów referencyjnych szpitali.

21 I. Rudawska, Opieka zdrowotna, aspekty rynkowe i marketingowe, Wydawnictwo Naukowe PWN, Warszawa 2007, s. 59. 
budżetem placówki. Płatnik natomiast traci możliwość oceny wartości dodanej, wynikającej z kompleksowości i ciągłości opieki, jaka może być udzielona pacjentowi w szpitalu wieloprofilowym.

Do negatywnych cech (zagrożeń) zakupu świadczeń należy również zaliczyć przyjęty negocjacyjny tryb ustalania warunków umów. Negocjacjom podlega odrębnie każda oferta $\mathrm{w}$ zakresie liczby i ceny zakupywanych świadczeń. W mojej ocenie negocjacje są najsłabszym punktem procesu zawierania umów. Mają one sens tylko w sytuacji, gdy obniżenie ceny ma wpływ na miejsce w rankingu końcowym ofert. Niektórzy świadczeniodawcy proponują w ofercie na tyle niską cenę, że dalsze jej obniżanie nie powoduje zwiększenia liczby punktów w rankingu ofert. Z tego względu od 2009 r. ci świadczeniodawcy nie muszą być zapraszani do negocjacji, tzn. ich oferta może zostać wybrana (lub odrzucona) z pominięciem procesu negocjacji. Zmniejsza to krąg świadczeniodawców biorących udział w negocjacjach, wciąż jednak jest to proces bardzo czasochłonny. Wadliwość takiego trybu wskazała również Najwyższa Izba Kontroli. Z raportu NIK ${ }^{22}$ wynika, że świadczeniodawca musi przyjąć propozycję komisji konkursowej praktycznie bez możliwości jej negocjowania. Potwierdzają to sami świadczeniodawcy, wskazując, że w toku negocjacji NFZ nie przekazuje zasad kalkulacji przedstawionej propozycji ceny oraz liczby świadczeń, a odmowa podpisania propozycji Funduszu jest równoznaczna z niezawarciem umowy. NIK wskazuje, że obecny model kontraktowania świadczeń powoduje, że głównym celem świadczeniodawców jest dążenie do zawarcia umowy z NFZ na jakichkolwiek warunkach. Aprobują oni ofertę Funduszu, aby wejść na rynek świadczeń i uzyskać finansowanie ze środków publicznych, licząc na zwiększenie wartości kontraktu w latach następnych.

Poważnym zagrożeniem dla obecnego modelu kontraktowania świadczeń jest brak zaufania pomiędzy stronami zawartej umowy. Świadczeniodawcy nie czują się równoprawnymi partnerami, traktując NFZ jako instytucję monopolistyczną, narzucającą im warunki umów. Warunki zawierania kontraktów nie są stabilne i zmieniają się co roku. Wpływa to niekorzystnie na obie strony umowy i uniemożliwia zawieranie kontraktów długoterminowych. Świadczeniodawcy próbują budować koalicje przeciw płatnikowi i wzrasta ich siła przetargowa, przez co płatnik nie może wywiązać się z ustawowego obowiązku zabezpieczenia świadczeń. Naciski świadczeniodawców przybierają najczęściej formę odmowy podpisywania kontraktów lub zgody na zawieranie umów tylko na krótkie okresy, np. 3 miesiące. Takie działania

22 Kontraktowanie świadczeń opieki zdrowotnej przez Narodowy Fundusz Zdrowia, informacja o wynikach kontroli Najwyższej Izby Kontroli z dnia 7 marca 2014 r., nr ewidencyjny 15/2014/P/12/145/LKR, s. 38-39. 
prowadzą do bardzo wysokich kosztów społecznych, gdyż pacjenci co roku są informowani o tym, że mogą nie otrzymać świadczeń. Brak umów zawartych na dłuższe okresy prowadzi do destabilizacji systemu, zwiększa niepewność stron kontraktu oraz generuje koszty przeprowadzania kolejnych, uzupełniających konkursów ofert.

\section{Wnioski}

Kontraktowanie świadczeń jest narzędziem wykorzystywanym przez płatnika do podziału ograniczonych środków finansowych pomiędzy świadczeniodawców. Narzędzie to umożliwia kreowanie struktury świadczeń, pożądanej z uwagi na zgłaszane przez pacjentów potrzeby, efektywność kosztową i jakość. Kontraktowanie umożliwia płatnikowi wdrożenie obowiązujących reguł dostępu do świadczeń, a także kształtowanie popytu i podaży w sposób, który ułatwia realizację przyjętej polityki zdrowotnej. Kontraktowanie jest więc narzędziem służącym do wprowadzenia rynku regulowanego i regulowanej konkurencji. Umożliwia stworzenie bodźców do udzielania świadczeń, które nie zawsze są opłacalne dla świadczeniodawcy, ale są niezbędne do zrealizowania głównego celu, którym jest poprawa zdrowia populacji. Kontraktowanie służy również wybraniu tych świadczeniodawców, którzy spełniają kryteria jakościowe oraz gwarantują prawidłową realizację świadczeń opieki zdrowotnej finansowanych ze środków publicznych. Analiza SWOT wykazała, że obecny model kontraktowania świadczeń wymaga korekty. Wydaje się, że najlepszą strategią do jej przeprowadzenia będzie podjęcie działań zmierzających do ograniczania zagrożeń oraz wzmocnienia mocnych stron obecnego modelu kontraktowania. W tym celu trzeba podjąć następujące działania:

1) Należy rozbudować narzędzia umożliwiające płatnikowi i Ministerstwu Zdrowia stałe monitorowanie zapotrzebowania na poszczególne zasoby systemu opieki zdrowotnej. Monitorowanie i ewaluacja zapotrzebowania w zakresie infrastruktury, alokacji przestrzennej zasobów, a także prognoza zapotrzebowania na kadry medyczne mają kluczowe znaczenie dla poprawy efektywności i dostępności do świadczeń. Usprawnienie procesu zbierania i przetwarzania powyższych danych oraz przygotowanie narzędzia prognostycznego ułatwi proces podejmowania decyzji w zakresie alokowania środków publicznych. Należy pamiętać, że zasoby na rynku zdrowia mają charakter specyficzny i charakteryzują się niską elastycznością, z tego względu ich właściwe zaplanowanie ma szczególne znaczenie. Dobrym rozwiązaniem jest wprowadzenie konieczności sporządzania map potrzeb zdrowotnych oraz wydawania przez wojewodów decyzji o potrzebie 
powstania nowego świadczeniodawcy w regionie. Obecnie trudno jest ocenić skuteczność tych narzędzi, ponieważ zostały one wprowadzone dopiero w $2015 \mathrm{r}$.

2) Należy wzmocnić etap planowania świadczeń i połączyć go $z$ aktywnym zarządzaniem zasobami w opiece zdrowotnej. W tym zakresie należy wprowadzić regularną analizę potrzeb zdrowotnych i włączyć w to szerszy krąg instytucji, w tym płatnika oraz instytucje regulujące rynek świadczeń.

3) Należy zróżnicować metody kontraktowania świadczeń w zależności od przedmiotu kontraktowania. W szczególności dotyczy to kontraktowania świadczeń wysokospecjalistycznych, które ze względu na wysokie koszty i rzadkość zasobów oraz wąską grupę świadczeniobiorców korzystających z tych świadczeń powinny być kontraktowane na szczeblu centralnym (nie zaś tak jak obecnie przez każdy oddział NFZ odrębnie). Celem takiego działania jest obniżenie kosztów transakcyjnych i zwiększenie efektywności kosztowej, która będzie możliwa do osiągnięcia dzięki efektom skali i lepszemu wykorzystaniu zasobów. W efekcie takiego działania wzrośnie bezpieczeństwo pacjenta.

4) Należy ograniczyć przeprowadzenie konkursu ofert do zakupu świadczeń na rynku, na którym istnieje konkurencja między świadczeniodawcami, a wykluczyć go tam, gdzie tej konkurencji nie ma lub jest niepożądana. Obecną procedurę konkursową można stosować w przypadku ambulatoryjnej opieki specjalistycznej, natomiast dla lecznictwa zamkniętego, ze względu na specyfikę zasobów, należy zastosować inną metodę doboru świadczeniodawców, którzy mogą udzielać świadczeń w ramach ubezpieczenia zdrowotnego. Jednym z możliwych rozwiązań jest utworzenie sieci szpitali. Warunki wpisania na listę powinny być szczegółowo opisane w dokumencie rangi ustawowej.

5) Należy zmienić dotychczasowy tryb określania warunków umów oraz sposobu finansowania świadczeń oraz zapewnić ich stabilność (niezmienność) w długim okresie. Istotne warunki kontraktowania powinny być wypracowane w drodze konsensusu pomiędzy płatnikiem, świadczeniodawcami oraz instytucjami regulacyjnymi (głównie Ministerstwem Zdrowia) i mieć charakter trwały. Ewaluacja tych warunków powinna się odbywać również na drodze porozumienia wszystkich ww. stron. Sposób ewaluacji warunków kontraktowania świadczeń powinien następować zgodnie z wcześniej opracowaną procedurą, zawierającą wytyczne postępowania dla stron oraz zakres ich kompetencji.

6) Należy rozważyć wprowadzenie obowiązkowych raportów kosztowych sporządzanych przez świadczeniodawców realizujących świadczenia finansowane ze środków publicznych. W mojej opinii obowiązkowe raporty kosztowe są niezbędne do właściwej wyceny świadczeń. W tym celu należy opracować jednolity sposób ewidencjonowania i grupowania kosztów oraz jednolity format raportowania 
o kosztach. Raporty kosztowe mogłyby pełnić również rolę narzędzia służącego do oceny efektywności kosztowej świadczeniodawców.

7) Należy dopracować standardy jakościowe udzielania świadczeń. W tym zakresie płatnik powinien wzmocnić współpracę z Centrum Monitorowania Jakości w Ochronie Zdrowia. Standardy akredytacyjne powinny mieć szerokie zastosowanie również w opiece ambulatoryjnej. Należy zwiększyć rolę akredytacji jako instrumentu potwierdzającego dobrą jakość świadczeniodawców i powiązać posiadanie akredytacji z uzyskaniem przewagi konkurencyjnej na rynku.

8) Należy umożliwić płatnikowi większą swobodę we wprowadzaniu modeli kontraktowania, które umożliwią koordynowanie opieki nad pacjentem. W tym zakresie należy zastąpić dotychczasowe kontraktowanie wąskich zakresów świadczeń finansowaniem kompleksowej opieki nad pacjentem. Takie działanie zmniejszy negatywne skutki defragmentacji procesu leczenia oraz wymusi właściwy przepływ informacji pomiędzy świadczeniodawcami odpowiedzialnymi za koordynację leczenia pacjenta.

9) Należy podjąć działania mające na celu włączenie pacjentów w aktywne podejmowanie decyzji i wpływanie na istotne elementy systemu opieki zdrowotnej. W tym zakresie powinno się prowadzić szeroką edukację pacjentów w obszarze profilaktyki i prewencji, zachowań prozdrowotnych, ale również praw i obowiązków pacjentów. Świadomy pacjent dokonuje lepszych wyborów oraz zwiększa swoją aktywność w obszarze kontroli decyzji lekarskich.

\section{Bibliografia}

Health at a Glance: Europe 2014, OECD Publishing 2014, www.oecd.org

Kontraktowanie świadczeń opieki zdrowotnej przez Narodowy Fundusz Zdrowia, informacja o wynikach kontroli Najwyższej Izby Kontroli z dnia 7 marca 2014 r., nr ewidencyjny 15/2014/P/12/145/LKR.

Od ekonomii do ekonomii zdrowia. Podręcznik ekonomiki zdrowia, red. S. Golinowska, Wydawnictwo Naukowe PWN, Warszawa 2015.

Rozporządzenie Ministra Zdrowia z dnia 22 grudnia 2014 r. w sprawie sposobu ogłaszania o postępowaniu w sprawie zawarcia umowy o udzielanie świadczeń opieki zdrowotnej, składania ofert, powoływania i odwoływania komisji konkursowej, jej zadań oraz trybu pracy, DzU 2014, poz. 1980.

Rozporządzeniu Ministra Zdrowia z dnia 5 sierpnia 2016r. w sprawie szczegółowych kryteriów oceny ofert w postępowaniu w sprawie zawarcia umów o udzielanie świadczeń opieki zdrowotnej, DzU 2016, poz. 1372. 
Rudawska I., Opieka zdrowotna, aspekty rynkowe i marketingowe, Wydawnictwo Naukowe PWN, Warszawa 2007.

Sprawozdania finansowe Narodowego Funduszu Zdrowia za lata 2008-2014, www.nfz.gov.pl

Ustawa z dnia 27 sierpnia 2004 r. o świadczeniach opieki zdrowotnej finansowanych ze środków publicznych, DzU 2015, poz. 581 z późn. zm.

Ustawa z dnia 22 lipca 2014 r. o zmianie ustawy o świadczeniach opieki zdrowotnej finansowanych ze środków publicznych oraz niektórych innych ustaw, DzU 2014, poz. 1138.

Williamson O., Ekonomiczne instytucje kapitalizmu, Wydawnictwo Naukowe PWN, Warszawa 1998.

Zarządzenie nr 3/2014/DSOZ Prezesa Narodowego Funduszu Zdrowia z dnia 23 stycznia 2014 r. w sprawie określenia kryteriów oceny ofert w postępowaniu w sprawie zawarcia umowy o udzielanie świadczeń opieki zdrowotnej (z późn. zm.), www.nfz.gov.pl

Zdrowie i ochrona zdrowia w 2014 r., Główny Urząd Statystyczny, Warszawa 2015.

\section{Contracting health care benefits by the Polish National Health Found: an attempt at SWOT analysis}

Contracting of health care benefits is a very important tool that allows a payer to create desired structure, considering the needs notified by the patients, the cost-effectiveness and the quality of the benefits. Contracting is aimed at attaining a number of important tasks such as the implementation of the existing rules of access to health care and the development of supply and demand in a way that facilitates the implementation of the adopted health policy. Contracting of health care benefits is thus an important tool enabling to introduce the regulated market and regulated competition. Therefore, a correct model for contracting of benefits is essential for correct exchanges of the limited (and specific) resources on the healthcare market.

The purpose of this article is to assess the contracting of health care benefits by the National Health Fund. The following areas impacting on contracting of benefits were analysed: sources of financing, benefits purchase planning, valuation of benefits and the procedures for the award of contracts. A SWOT analysis was used to perform the analysis.

At present the contracting of health care benefits in Poland is regulated by the Act of 27 August 2004 on health care benefits financed from public funds (consolidated text: Journal of Laws 2015, item 581, as amended). The article describes the legal situation on 31 March 2016. The conclusions from the analysis confirm 
the need for change, in particular by improving the cost efficiency and the implementation of activities promoting comprehensive care of a patient.

Keywords: contracting of health care benefits, National Health Fund

\section{La procédure de contractualisation des prestations de soins de santé par le Fonds national de la santé. Tentative d'analyse SWOT}

La contractualisation des prestations de soins de santé est un outil très important qui permet au payeur de créer la structure désirée, compte tenu des besoins formulés par les patients, de la rentabilité et de la qualité des prestations. La contractualisation vise à réaliser un nombre considérable de tâches importantes telles que la mise en ouvre des règles d'accès aux soins de santé en vigueur et le développement de l'offre et de la demande de manière à faciliter la réalisation de la politique de santé adoptée. La contractualisation des prestations de soins de santé est donc un outil important permettant d'introduire le marché réglementé et la concurrence réglementée. Par conséquent, créer un bon modèle de contractualisation est essentiel pour un bon échange des ressources limitées (et spécifiques) sur le marché de la santé.

Le but de cet article est d'évaluer le modèle de la contractualisation des prestations de soins de santé par le Fonds national de la santé. Les domaines suivants ayant un impact sur la sous-traitance des prestations ont été analysés: les sources de financement, la planification des achats de prestations, l'évaluation des prestations et les procédures d'attribution des contrats. Une analyse SWOT a été utilisée pour effectuer cette évaluation.

Actuellement, la contractualisation des prestations de soins de santé en Pologne est régie par la loi du 27 août 2004 sur les prestations de soins de santé financées par des fonds publics [texte consolidé: Dziennik Ustaw (Journal Officiel) 2015, point 581, amendé]. L'article décrit la situation juridique au 31 mars 2016. Les conclusions de l'analyse confirment la nécessité d'un changement, notamment en améliorant la rentabilité et la mise en œuvre d'actions favorisant la prise en charge globale du patient.

Mots-clés: contractualisation des prestations de soins de santé, Fonds national de la santé 


\section{Процедура заключения Национальным фондом здравоохранения договоров на предоставление медицинских услуг. Попытка анализа SWOT}

Заключение контрактов на медицинские услуги является очень важным инструментом, позволяющим плательщику создать желаемую структуру услуг, учитывая сообщаемые пациентами потребности, экономическую эффективность и качество услуг. Оно направлено на достижение ряда важных задач, таких как реализация принципа доступа к медицинской помощи или развитие спроса и предложения так, чтобы облегчит реализацию принятой политики в области здравоохранения. Таким образом, является важным инструментом, позволяющим ввести регулируемый рынок и регулируемую конкуренцию. Поэтому, правильная модель заключения договоров на предоставление медицинских услуг имеет важное значение для правильного обмена ограниченными (и специфическими) ресурсами на рынке здравоохранения.

Цель статьи состоит в оценке заключения Национальным фондом здравоохранения договоров на предоставление медицинских услуг. Анализу подверглись следующие области, имеющие влияние на заключение контрактов: источники финансирования, планирование приобретения медицинских услуг, определение стоимости медицинских услуг и процедуры присуждения контрактов. В работе был использован анализ SWOT.

В настоящее время заказ медицинских услуг в Польше регулируется Законом от 27 августа 2004 года о медицинских услугах, финансируемых за счет государственных средств (сводный текст: Законодательный вестник 2015, позиция 581, с последующими изменениями). В статье описывается правовое положение по состоянию на 31 марта 2016 г. Выводы по результатам анализа подтверждают необходимость изменений, в частности повышения эффективности расходов и внедрения действий, способствующих комплексному уходу за пациентом.

Ключевые слова: заключение договоров на предоставление медицинских услуг, Национальный фонд здравоохранения 